\title{
THE POTENTIAL OF ROAD PRICING SCHEMES FOR REDUCING CARBON EMISSIONS
}

\begin{abstract}
Road pricing is a transport measure mainly conceived to fund road management, to regulate the demand for traffic and to reduce the number of private vehicles circulating in urban areas. It can also grant benefits in terms of environmental externalities including the reduction of $\mathrm{CO}_{2}$ emissions, which has recently become one of the most important elements defining the sustainability of a transport system. However, the carbon potential granted by road charging is rarely assessed, thus confirming a sort of secondary role attributed to $\mathrm{CO}_{2}$ in urban premises. This paper provides an accurate analysis of the relationship between the different forms of road pricing (including distance-based, congestion-based and pay-as-you-drive) and their effective role in terms of carbon reduction, which in some contexts is higher than $10 \%$. Furthermore, practical suggestions to policy makers in terms of implementation of the measure are discussed, highlighting the precautions necessary to include a fair carbon evaluation into an overall effective analysis.
\end{abstract}

\section{Keywords}

$\mathrm{CO}_{2}$ Emissions, Congestion Based Road Pricing, Distance Based Road Pricing, Pay-as-you-drive, transport policy.

JEL codes

R4 Transportation Systems

\section{Highlights}

- The potentialities of road pricing in terms of carbon reduction are assessed

- The analysis includes Congestion Based, Distance Based Pricing and Pay-as-You-Drive

- Results reveals a significant potential reduction of $\mathrm{CO}_{2}$ emissions, higher than $10 \%$

- Policy makers have to be aware about the social acceptance and the use of revenues 


\section{INTRODUCTION}

Recent climate talks attempted to tackle several pressing transport issues, including global emissions, related temperature targets, and cooperation towards the production of clean energy for alternative vehicles. Despite this breadth of topics and the acknowledged importance of transport within the climate issue (EC, 2009), mobility plans and traffic measures tend to primarily address other issues (Nocera and Cavallaro, 2014a). Particularly, there is still a relatively limited discussion on the possible role of pricing strategies in reducing greenhouse gas emissions (GHGs).

Road pricing has received a considerable interest in the last 30 years (Newbery, 1990; Yang and Bell, 1997; Small and Yan, 2001; Washbrook et al., 2006; Rotaris et al., 2010; Vonk Noordegraaf et al., 2014). Cutting a very long story short, this measure is aimed in two main directions, namely the funding of road management and the regulation of demand for road traffic. However, literature identifies many other impacts, born directly from transport producers, from the road users, and from the community (Sinha and Labi, 2007): some of them can be determined easily, while others are expected to emerge in the long term and need some appropriate policy making. The rationale behind road pricing strategies is straightforward. The marginal cost of a road trip is higher than the direct cost perceived by the driver or the operator, as the external costs are partly transferred to other agents. Other users or the community may incur in them, respectively in the forms of congestion and lost time, air and noise pollution, or costs of accidents. As a result, decisions about road trips made by individuals are biased, since the comparison between costs and benefits does not include all the elements. This leads to a suboptimal allocation of resources and becomes extremely critical in countries with serious haze problems, in which local government authorities should pay extreme attention to environmental protection. For these reasons, the objective function should correctly consider both congestion and environmental factors, hence counting carbon emissions properly. Their inclusion should be easily identified because of the important role played by transport within climate change issues, even if this may set huge evaluation problems that raise the complexity of the subject (Nocera et al., 2015a).

This paper investigates the potential role of road pricing in granting a saving of $\mathrm{CO}_{2}$ emissions. Section two presents a classification and description of the different forms of road charging, including their $\mathrm{CO}_{2}$ benefits. Section three describes some of the most relevant experiences at an international level and their implications in terms of carbon reduction. Section four comments on the results of such experiences, discussing the potentiality of this measure and the necessary precautions that policy makers should adopt during the preliminary assessments and the implementation of the measure. The paper concludes with some policy considerations that highlight the role of a correct evaluation of GHG emissions.

\section{ROAD PRICING AND CARBON EMISSIONS}

Road pricing is one of the most relevant "push-measures", conceived to shift freight and passengers from less to more sustainable transport systems by adopting financial instruments (e.g. taxes, charges and tolls) or technical and regulatory constraints (e.g. orders and bans). Road pricing belongs to the former group aiming at lowering traffic volumes by raising travel costs. This is expected to reduce private transport, generate revenues and control congestion problems. Road pricing systems are rather heterogenic, including at least three subcategories: distance based, congestion based and pay-as-you-drive insurance (Antonissen et al., 2013). Distance based road pricing implies a higher price per km travelled - valid both at urban and at extra urban level, in order to internalize the external costs of transport. Differentiations can be introduced according to the vehicle specification: for example, cleaner or alternative cars may pay less, according to the reduced environmental 
impacts. Congestion based road pricing is a tax applied to specific areas. Vehicle owners that want to enter this controlled area have to pay a fee, which could be valid for a single or a daily access with different rates according to the time. It aims at granting a reduction of traffic congestion, at the same time lowering travel time and improving the reliability of public transport mostly in city centres, which are known to be highly congested due to the lack of space and the presence of many activities and facilities. Pay-as-you-drive insurance (PAYD) involves replacing existing lump-sum premiums with premiums that vary in proportion to the miles driven. PAYD is contrary to the current insurance pricing, based on an inequitable "all-you-can-drive" scheme: low-mileage drivers subsidize insurance costs for high-mileage drivers, and low-income people drive fewer miles on average. On the contrary, PAYD tries to connect the insurance costs proportionally to the km driven.

Road pricing is expected to improve not only urban traffic conditions, but also the environmental quality of the areas where it is implemented (Banister, 2003), helping reduce other transport externalities such as local air pollution and the frequency of accidents. Literature about the environmental issues addressed by road pricing is wide and focusses mostly on criteria pollutants, such as CO, NOx and PM (Gulipalli and Kockelman, 2008; Frey, 2010; Jensen et al., 2011; Ferreira et al., 2012; Fensterer et al, 2014; Goodman et al., 2014; Wolff, 2014; Ezeah et al., 2015; AIRUSE, 2015; Coria et al, 2015). Indeed, road pricing is not typically seen as a $\mathrm{CO}_{2}$ reducing measure per se (Mitchell et al, 2005): its carbon effects are considered additional and thus they are not the object of a specific assessment (Harmsen et al, 2003). Despite this general ancillary role assigned to $\mathrm{CO}_{2}$ impacts, some studies underlined the importance of their fair evaluation: The Working Group on ICT for Clean and Efficient Mobility (Kompfner and Reinhardt, 2008) and the ECOSTAND project (Shladover et al, 2011), born from the cooperation between the European Union, Japan, and U.S.A., identified road pricing as one of the main Intelligent Transport Systems that could have a relevant impact on $\mathrm{CO}_{2}$ emissions from road transport. Also the iMobility forum and the Working Group for Clean and Efficient Mobility (WG4CEM; Antonissen et al., 2013) included road pricing among those measures able to grant good results in terms of $\mathrm{CO}_{2}$ reduction (expected effects are higher than 10\%), on the basis of the few results produced by the EU projects assessed. In this section, we integrate the indications given by the previous studies, by providing a quite extensive literature review, which enables us to understand the state of the art and the relationship between $\mathrm{CO}_{2}$ emissions and road pricing measures. This kind of analysis, which has already been provided for some alternative transport measures (e.g., eco-routing - Alam and McNabola, 2014), can be particularly helpful for policy makers to understand the implications and the potentialities in view of the adoption of the measure.

A list of the studies and projects that deal specifically with $\mathrm{CO}_{2}$ emissions and road pricing measures is presented in the following tables 1-3. Unitary tolls, implementation costs and incomes are reported in the same economic value (€2015), to make them comparable. For sake of clarity, we have kept the distinction between congestion based road pricing, distance based road pricing and PAYD. Congestion based road pricing (table 1) describes 25 case studies, mostly located in Europe. The size and the number of inhabitants of the cities show that this system is assessed both in medium and large contexts, the latter being more numerous. Distance based road pricing (table 2) illustrates 10 case studies, also in this case mostly referred to European cities. Except for the city of Santa Clara, the whole of them is based on simulations and not on measurements or ex-post evaluations. Finally, PAYD (table 3) is limited to five cases. The reason that almost all the PAYD studies are based on simulations is due to the fact that the development of this measure is still recent; several legislative and technical issues made its introduction difficult. Contrary to the two previous sections, most of the assessments are referred to the U.S.A., with an application in different States. Being mostly referred to the national level (e.g., California, Oregon, and Massachusetts) and not to the municipal scale, the number of inhabitants that is involved is bigger than the previous measures. 
CIT2016 - XII Congreso de Ingeniería del Transporte

València, Universitat Politècnica de València, 2016.

DOI: http://dx.doi.org/10.4995/CIT2016.2016.3215

\begin{tabular}{|c|c|c|c|c|c|c|c|c|c|c|c|}
\hline \multicolumn{12}{|c|}{ CONGESTION BASED ROAD PRICING } \\
\hline \multirow[t]{2}{*}{ City } & \multirow{2}{*}{$\begin{array}{l}\text { Date } \\
\text { Year }\end{array}$} & \multirow[t]{2}{*}{$\begin{array}{l}\text { Study } \\
\text { type }\end{array}$} & \multirow{2}{*}{$\begin{array}{l}\text { Toll } \\
\epsilon_{2015}\end{array}$} & \multirow{2}{*}{\begin{tabular}{c|}
$\begin{array}{c}\mathrm{CO}_{2} \\
\text { Reduction }\end{array}$ \\
$\%$
\end{tabular}} & \multirow{2}{*}{$\begin{array}{c}\text { City } \\
\text { Area } \\
\mathrm{km}^{2}\end{array}$} & \multirow{2}{*}{$\begin{array}{c}\begin{array}{c}\text { City } \\
\text { Inhabitants }\end{array} \\
\text { nr. }\end{array}$} & \multirow{2}{*}{\begin{tabular}{|c|} 
Implementation \\
$\mathbf{M} €_{2015}$
\end{tabular}} & \multirow{2}{*}{$\begin{array}{c}\text { Income } \\
\mathbf{M}_{2015} / \\
\text { year }\end{array}$} & \multicolumn{3}{|c|}{ Others Pollutants } \\
\hline & & & & & & & & & $\mathrm{NO}_{\mathrm{x}}$ & PM & co \\
\hline Stockholm (SE) & 2006 & C & $\begin{array}{l}1.23 \\
2.46\end{array}$ & $\begin{array}{l}-13.0 \% \\
-5.4 \%^{*} \\
-2.7 \%^{* \star}\end{array}$ & 188 & 776,962 & - & 78.8 & $\sqrt{ }$ & $\sqrt{ }$ & $\sqrt{ }$ \\
\hline London (UK) & 2003 & C & 8.29 & $-19.9 \%$ & 1,572 & $7,364,100$ & - & - & $\sqrt{ }$ & $\sqrt{ }$ & - \\
\hline London (UK) & \begin{tabular}{|c|}
2003 \\
$/ 2007$
\end{tabular} & C & 10.47 & $\begin{array}{l}-16.0 \% \\
-1.0 \%{ }^{*}\end{array}$ & 1,572 & $7,364,100$ & 130.0 & 149.6 & $\sqrt{ }$ & $\sqrt{ }$ & - \\
\hline Auckland (NZ) & - & $S$ & $\begin{array}{l}1.70 \\
3.53 \\
2.94\end{array}$ & $-9.80 \%$ & 1,086 & $1,387,800$ & 71.2 & 139.5 & $\sqrt{ }$ & $\sqrt{ }$ & $\sqrt{ }$ \\
\hline $\begin{array}{l}\text { San Francisco } 1 \\
\text { (USA) } ¥\end{array}$ & - & S & 2.24 & $\begin{array}{l}-7.0 \% \\
-4.0 \%{ }^{*}\end{array}$ & 121 & 805,704 & $46.0 / 76.7$ & 272 & - & $\sqrt{ }$ & - \\
\hline $\begin{array}{c}\text { San Francisco } 2 \\
(\text { USA }) ¥\end{array}$ & - & $S$ & 4.47 & $\begin{array}{l}-9.0 \% \\
-3.0 \% *\end{array}$ & 121 & 805,704 & $46.0 / 76.7$ & 272 & - & $\sqrt{ }$ & - \\
\hline $\begin{array}{l}\text { San Francisco } 3 \\
\text { (USA) } ¥\end{array}$ & - & $S$ & 2.24 & $\begin{array}{l}-16.0 \% \\
-5.0 \%{ }^{*}\end{array}$ & 121 & 805,704 & $46.0 / 76.7$ & 197 & - & $\sqrt{ }$ & - \\
\hline Milan (IT) & 2012 & C & $\begin{array}{l}2.05 \\
5.13\end{array}$ & $-15.0 \%$ & 182 & $1,251,000$ & - & - & $\sqrt{ }$ & $\sqrt{ }$ & - \\
\hline London (GB) & 2020 & S & $\begin{array}{l}19.02 \\
151.1\end{array}$ & $\begin{array}{l}-15.0 \% \\
-3.0 \%{ }^{*}\end{array}$ & 1,572 & $8,539,000$ & - & 18.0 & $\sqrt{ }$ & - & - \\
\hline Singapore & 1998 & C & - & - & 132 & $5,535,000$ & 92.2 & 36.7 & - & - & - \\
\hline Cambridge (GB) & 2016 & S & $\begin{array}{l}0.93 \\
6.61\end{array}$ & $-8.0 \%$ & 41 & 128,515 & 22.5 & - & - & - & - \\
\hline Copenhagen (DK) & \begin{tabular}{|c|}
2001 \\
/ 2003
\end{tabular} & C & $\begin{array}{l}10.32 \\
5.16\end{array}$ & $-(1.0 / 3.0 \%)^{\star \star}$ & 86 & 499,148 & - & - & $\sqrt{ }$ & $\sqrt{ }$ & \\
\hline Edinburgh (Scotland) & - & S & 1.29 & $-12.3 \%$ & 264 & 495,360 & - & - & - & - & - \\
\hline Leeds $1(\mathrm{~GB}) \neq$ & - & $\mathrm{S}$ & 4.98 & $-2.0 \%$ & 487 & 429,242 & - & - & $\sqrt{ }$ & $\sqrt{ }$ & $\sqrt{ }$ \\
\hline Leeds $2(G B) \neq$ & - & $S$ & $3.32+1.66$ & $-18.0 \%$ & 487 & 429,242 & - & - & $\sqrt{ }$ & $\sqrt{ }$ & $\sqrt{ }$ \\
\hline Cambridge $(G B) \approx$ & - & $S$ & $\begin{array}{l}1.61 \\
2.14 \\
3.21\end{array}$ & $\begin{array}{l}-1.4 \% \\
-3.2 \% \\
-5.7 \%\end{array}$ & 41 & 108,863 & - & - & $\sqrt{ }$ & $\sqrt{ }$ & $\sqrt{ }$ \\
\hline Northampton $(G B) \approx$ & - & $S$ & $\begin{array}{l}6.42 \\
7.50\end{array}$ & $\begin{array}{c}-(1.6 / 3.2 \%) \\
-5.9 \%\end{array}$ & 81 & 194,458 & - & - & $\sqrt{ }$ & $\sqrt{ }$ & $\sqrt{ }$ \\
\hline Kingston $(G B) \approx$ & - & $S$ & $\begin{array}{l}5.36 \\
6.42 \\
7.50\end{array}$ & $\begin{array}{l}-4.6 \% \\
-7.2 \% \\
-9.7 \%\end{array}$ & 72 & 243,595 & - & - & $\sqrt{ }$ & $\sqrt{ }$ & $\sqrt{ }$ \\
\hline Hereford $(G B) \approx$ & - & $S$ & $\begin{array}{l}3.21 \\
3.75 \\
7.50\end{array}$ & $\begin{array}{l}-14.2 \% \\
-11.6 \% \\
-10.4 \%\end{array}$ & - & - & - & - & $\sqrt{ }$ & $\sqrt{ }$ & $\sqrt{ }$ \\
\hline Lincoln $(G B) \approx$ & - & $S$ & $\begin{array}{l}0.53 \\
1.08 \\
2.14\end{array}$ & $\begin{array}{l}-4.0 \% \\
-2.0 \% \\
-2.7 \%\end{array}$ & 36 & 119,541 & - & - & $\sqrt{ }$ & $\sqrt{ }$ & $\sqrt{ }$ \\
\hline Bedford $(G B) \approx$ & - & $S$ & $\begin{array}{l}0.53 \\
1.08 \\
2.14\end{array}$ & $\begin{array}{l}-2.0 \% \\
-2.7 \% \\
-12.9 \%\end{array}$ & - & - & - & - & $\sqrt{ }$ & $\sqrt{ }$ & $\sqrt{ }$ \\
\hline $\begin{array}{l}\text { Norwich } \\
(\mathrm{GB}) \approx\end{array}$ & - & $S$ & $\begin{array}{l}1.08 \\
1.61\end{array}$ & $\begin{array}{l}-2.0 \% \\
-3.4 \%\end{array}$ & 39 & 121,553 & - & - & $\sqrt{ }$ & $\sqrt{ }$ & $\sqrt{ }$ \\
\hline York $(G B) \approx$ & - & $S$ & $\begin{array}{l}1.61 \\
3.21\end{array}$ & $\begin{array}{c}-(2.0 / 2.6 \%) \\
-5.0 \%\end{array}$ & 272 & 181,131 & - & - & $\sqrt{ }$ & $\sqrt{ }$ & $\sqrt{ }$ \\
\hline Wellington $(\mathrm{NZ}) \cap$ & - & S & $1.28 / 5.10$ & $-16.0 \%$ & 444 & 190,956 & $7.1 / 8.5$ & - & $\sqrt{ }$ & $\sqrt{ }$ & $\sqrt{ }$ \\
\hline Wien (AT) & - & $S$ & - & $\begin{array}{c}-4.0 \% \\
-(8.0 / 9.0 \%)^{*}\end{array}$ & 414 & $1,700,000$ & - & - & - & - & - \\
\hline $\begin{array}{l}\text { Notes: } § \mathrm{~S}=\text { Simulation. } \\
\text { and }{ }^{* \star}\left(\mathrm{CO}_{2} \text { Emissions a }\right. \\
\text { of the area in the second } \\
\text { tool range }\end{array}$ & $\begin{array}{l}C=\text { Case } \\
\text { re related } \\
\text { d case; } \approx\end{array}$ & $\begin{array}{l}\text { study } \mathrm{w} \\
\text { to the } n \\
=\mathrm{CO}_{2} \text { in }\end{array}$ & $\begin{array}{l}\text { easured va } \\
\text { ppolitan are } \\
t \text { is relate al }\end{array}$ & $\begin{array}{l}; \# \mathrm{CO}_{2} \text { reducti } \\
\text { refers to differe } \\
\text { o elasticity; } \cap=\end{array}$ & ers to & $\begin{array}{l}\text { arging area, } \\
\text { uration; } \neq \text { refe } \\
\text { led in the ran }\end{array}$ & $\begin{array}{l}\mathrm{pt} \mathrm{for}{ }^{*}\left(\mathrm{CO}_{2} \mathrm{Er}\right. \\
\text { o different cordc } \\
\text { lepends by day }\end{array}$ & $\begin{array}{l}\text { ons are } \\
\text { nfigurat } \\
\mathrm{CO}_{2} \text { in }\end{array}$ & $\begin{array}{l}\text { ted to } \\
\text { with a }\end{array}$ & ne enti & $\begin{array}{l}\text { e city) } \\
\text { ement } \\
\text { for the }\end{array}$ \\
\hline
\end{tabular}

Table 1 - Congestion based road pricing: impacts on $\mathrm{CO}_{2}$ emissions 


\begin{tabular}{|c|c|c|c|c|c|c|c|c|c|c|c|}
\hline \multicolumn{12}{|c|}{ DISTANCE BASED ROAD PRICING } \\
\hline \multirow[t]{2}{*}{ City } & \multirow{2}{*}{$\begin{array}{l}\text { Date } \\
\text { Year }\end{array}$} & \multirow[t]{2}{*}{$\begin{array}{l}\text { Study } \\
\text { type } \S\end{array}$} & \multirow{2}{*}{$\begin{array}{l}\text { Toll } \\
€_{2015}\end{array}$} & \multirow{2}{*}{$\begin{array}{c}\begin{array}{c}\mathrm{CO}_{2} \\
\text { Reduction }\end{array} \\
\%\end{array}$} & \multirow{2}{*}{$\begin{array}{c}\text { City } \\
\text { Area } \\
\text { km² }^{2}\end{array}$} & \multirow{2}{*}{$\begin{array}{c}\begin{array}{c}\text { City } \\
\text { Inhabitants }\end{array} \\
\text { nr. }\end{array}$} & \multirow{2}{*}{\begin{tabular}{|c|} 
Implementation \\
$\mathbf{M}_{2015}$
\end{tabular}} & \multirow{2}{*}{$\begin{array}{c}\text { Income } \\
M €_{2015} / \\
\text { year }\end{array}$} & \multicolumn{3}{|c|}{ Others Pollutants } \\
\hline & & & & & & & & & $\mathrm{NO}_{\mathrm{x}}$ & PM & $\mathrm{CO}$ \\
\hline $\begin{array}{c}\text { Cambridge } \\
\text { (GB) }\end{array}$ & - & $S$ & 0.76 & $-36.0 \%$ & 41 & 100,000 & - & - & & & \\
\hline $\begin{array}{l}\text { Edinburgh } \\
\text { (GB) }\end{array}$ & - & $S$ & $\begin{array}{l}0.85 \\
0.88\end{array}$ & $-18.1 \%$ & 264 & 495,360 & - & - & - & - & - \\
\hline $\begin{array}{l}\text { Leeds } \\
\text { (GB) }\end{array}$ & - & $S$ & 0.40 & $-12.0 \%$ & 487 & 429,242 & - & - & $\sqrt{ }$ & $\sqrt{ }$ & $\sqrt{ }$ \\
\hline $\begin{array}{c}\text { Santa Clara } \\
\text { (USA) }\end{array}$ & 2012 & C & - & $-17.0 \%$ & 3,377 & $1,800,000$ & 116.6 & 544.4 & - & - & - \\
\hline $\mathrm{CH}$ & 2001 & C & $\#$ & $-6.0 \%$ & 41,285 & $8,081,000$ & - & - & - & - & - \\
\hline Sydney (AUS) & 2015 & $S$ & 0.07 & $-4.7 \%$ & 12,367 & $4,605,000$ & - & - & - & - & - \\
\hline $\begin{array}{l}\text { Sydney } \\
\text { (AUS) } \triangle\end{array}$ & 2015 & $S$ & 0.03 & $-15.0 \%$ & 12,367 & $4,605,000$ & - & - & - & - & - \\
\hline $\mathrm{NL}$ & \begin{tabular}{|c|}
2012 \\
/ 2018 \\
\end{tabular} & $S$ & 0.005 & $-10.0 \%$ & 41,543 & $16,600,000$ & - & - & - & $\sqrt{ }$ & - \\
\hline GB & 2015 & $S$ & 0.35 & $-6.0 \%$ & 242,495 & $59,900,000$ & - & 5237.4 & - & - & - \\
\hline GB & 2015 & $S$ & 0.57 & $-9.0 \%$ & 242,495 & $59,900,000$ & - & 10474.8 & - & - & - \\
\hline
\end{tabular}

Table 2 - Distance based road pricing: impacts on $\mathrm{CO}_{2}$ emissions

\begin{tabular}{|c|c|c|c|c|c|c|c|c|c|c|c|}
\hline \multicolumn{12}{|c|}{ PAY-AS-YOU-DRIVE } \\
\hline \multirow[t]{2}{*}{ City } & \multirow{2}{*}{$\begin{array}{l}\text { Date } \\
\text { Year }\end{array}$} & \multirow[t]{2}{*}{$\begin{array}{l}\text { Study } \\
\text { type }\end{array}$} & \multirow{2}{*}{$\begin{array}{l}\text { Toll } \\
€_{2015}\end{array}$} & \multirow{2}{*}{$\begin{array}{c}\mathrm{CO}_{2} \text { Reduction } \\
\%\end{array}$} & \multirow{2}{*}{$\begin{array}{c}\text { City } \\
\text { Area }\end{array}$} & \multirow{2}{*}{$\begin{array}{c}\text { City } \\
\text { Inhabitants }\end{array}$} & \multirow{2}{*}{$\begin{array}{c}\text { Implementation } \\
\mathbf{M} €_{2015}\end{array}$} & \multirow{2}{*}{$\begin{array}{c}\text { Income } \\
\mathrm{M}_{2015} / \\
\text { year }\end{array}$} & \multicolumn{3}{|c|}{$\begin{array}{c}\text { Others } \\
\text { Pollutants }\end{array}$} \\
\hline & & & & & & & & & $\mathrm{NO}_{\mathrm{x}}$ & PM & CO \\
\hline $\begin{array}{l}\text { California } \\
\text { (USA) }\end{array}$ & 2020 & $S$ & $0.06 /$ mile & $-8.0 \%$ & 423,970 & $36,600,000$ & $7,403.7$ & - & - & - & - \\
\hline \begin{tabular}{|c|} 
Massachusetts \\
(USA)
\end{tabular} & - & $S$ & - & $-9.5 \%$ & 27,334 & $6,557,000$ & - & - & - & - & - \\
\hline GB & 2010 & $C$ & 30.72/day & $-12.0 \%$ & 242,495 & $63,260,000$ & - & - & $\sqrt{ }$ & $\sqrt{ }$ & - \\
\hline Oregon (USA) & - & $S$ & - & $-2.0 \%$ & 255,026 & $3,928,000$ & - & - & - & - & - \\
\hline USA & - & $S$ & $0.05 / \mathrm{mile}$ & $-8.5 \%$ & $9,857,000$ & $318,900,000$ & - & - & $\sqrt{ }$ & - & - \\
\hline
\end{tabular}

Table 3 - Pay-as-you-drive: impacts on $\mathrm{CO}_{2}$ emissions

\section{RELEVANT EXPERIENCES OF ROAD CHARGING AND $\mathrm{CO}_{2}$ EMISSIONS}

In this section, four of the most meaningful experiences described in tables 1-3 are analysed in more detail, to understand how road pricing schemes can work in some of the most important applications and their carbon implications. Referring to the congestion charge, "Area C" in Milan and the future Ultra Low Emission Zone in London are presented: the former being a real case and the latter a simulation. Distance based road pricing and PAYD are both results of simulations: for the former category, we refer to a national case study developed in the Netherlands; for the latter, we consider the PAYD insurance scheme tested in California. 


\subsection{Congestion charge in Milan}

Urban road pricing in Milan represents a best practice at European level, due to the longevity of the application and the results obtained, not only in terms of reduction of $\mathrm{CO}_{2}$ emissions (Rotaris et al, 2010; Percoco, 2013). The measure is based on a two-step process. The first road-pricing scheme (called Ecopass), ran from January 1, 2008 to December 31, 2011. Its name conveys the stated political objective of the scheme: a pass to improve the quality of the urban environment (Rotaris et al, 2010). The measure was launched in the central area of the city $\left(8.2 \mathrm{~km}^{2}\right)$, called "Cerchia dei Bastioni", from 7:30 a.m. to 7:30 p.m. on weekdays. The charge depended on a vehicle's engine emissions standard with fees of $0 €$ (for classes I and II), $2 €$ (Class III), $5 €$ (Class IV) and $10 €($ Class V) 1 , while free access was granted to motorbikes (Percoco, 2013). The city enforced the charge using license plate-reading cameras located at the 43 entrances to the area (Danielis et al., 2011; figure 1).

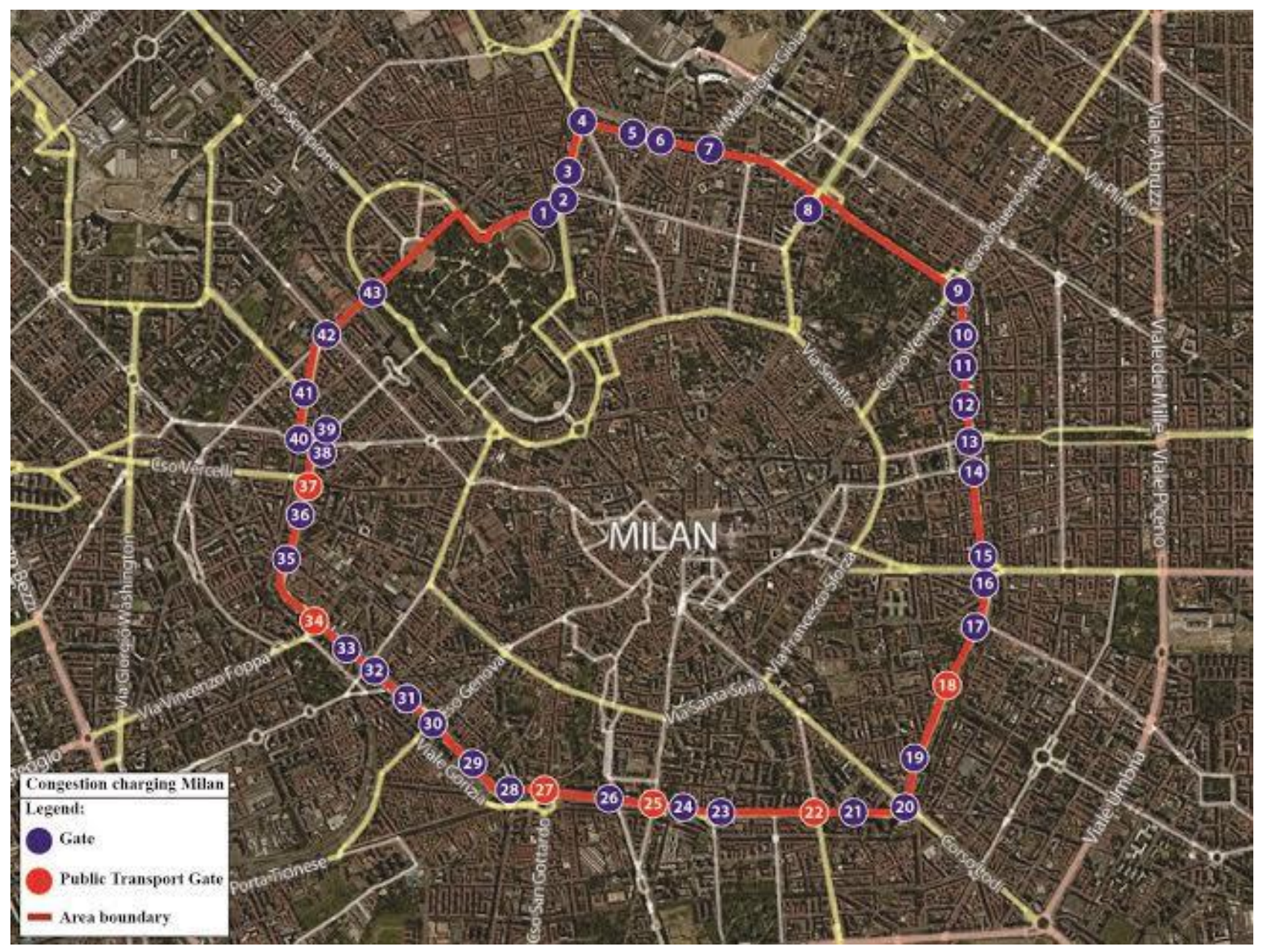

Fig. 1 - Road pricing gates in Milan

Drivers who entered without paying (about $2 \%$ of the total daily vehicles - Martino, 2012) faced fines between $70 €$ and $275 €$. In the first year after the introduction of the measure, traffic volume decreased by $21 \%$. In the first 6 months of 2010, the reduction compared to the do-nothing condition was 12\% (Strompen, 2016), with appreciable results also for air pollutants: $\mathrm{PM}_{10}$ decreased by $19 \%$, $\mathrm{NO}_{x}$ by $14 \%$, and $\mathrm{CO}_{2}$ by $15 \%$. On January

\footnotetext{
${ }_{1}$ Class I included the less polluting vehicles, powered by liquid propane gas, methane, electric and hybrid vehicles. Class II included Gasoline Euro III, IV or more recent, Diesel Euro IV without anti-particulate filter, cars and freight vehicles diesel Euro IV o more recent with anti-particulate filter. Class III was characterized by car powered by Gasoline, Euro I and II. Class IV consists of Gasoline Euro 0, Diesel cars Euro I-III, Diesel goods vehicles Euro III, Diesel buses Euro IV and V. Finally Class V included the most polluting vehicles: diesel cars Euro 0, goods vehicles Euro 0-II, diesel buses Euro 0-III).
} 
2012, the city council implemented a second and more restricted phase of this policy (currently ongoing), called "Area C". It is a $5 €$ congestion charge for all the vehicles entering this area, which has the same characteristics of Ecopass, during weekdays from 7:30 a.m. to 7:30 p.m. The most polluting vehicles (diesel cars powered by an engine Euro $0, \mathrm{I}, \mathrm{II}, \mathrm{III}$ and petrol cars powered by an engine Euro 0 ) are not allowed to circulate. Violators were fined $87 €$ (Gibson and Carnovale, 2015). Thanks to this measure, $\mathrm{CO}_{2}$ emissions in Area $\mathrm{C}$ have decreased by $33 \%$ compared to 2010 levels (AMAT, 2015).

\subsection{Ultra Low Emission Zone in London}

Ultra Low Emission Zone (ULEZ) is an innovative proposal for London, expected to be realized by 2020. It is conceived as an implementation of the Congestion Charging Zone (CCZ), a measure currently operative, which started in 2003 to solve traffic congestion and air pollution issues in central London (Beevers and Carslaw, 2004; Weinmann, 2014). CCZ covers a surface of $33 \mathrm{~km}^{2}$ and an estimated inner population of 200,000 inhabitants. Nowadays, the applied daily charge in CCZ is $£ 11.50$ ( $£ 10$ for all registered vehicles), with a penalty of $£ 130$ (reduced to $£ 65$ if paid within 14 days) for all vehicles detected while driving into the charging zone without permission (Transport for London, 2014b). This configuration led to a $16 \%$ reduction of $\mathrm{CO}_{2}$ emissions, compared to the previous layout (C40CITIES, 2011), which is considered a value not satisfactory for the high standards of the city. Indeed, according to the Mayor's Transport Strategy (MTS, 2014), in 2010 road transport was responsible for $21 \%$ of $\mathrm{CO}_{2}$ emissions of central London (Dix, 2013). Despite the introduction of the CCZ, this percentage is expected to increase to $26 \%$ by 2020 , if integrative robust measures are not introduced. With such premises, ULEZ has been proposed as a valid solution (figure 2).

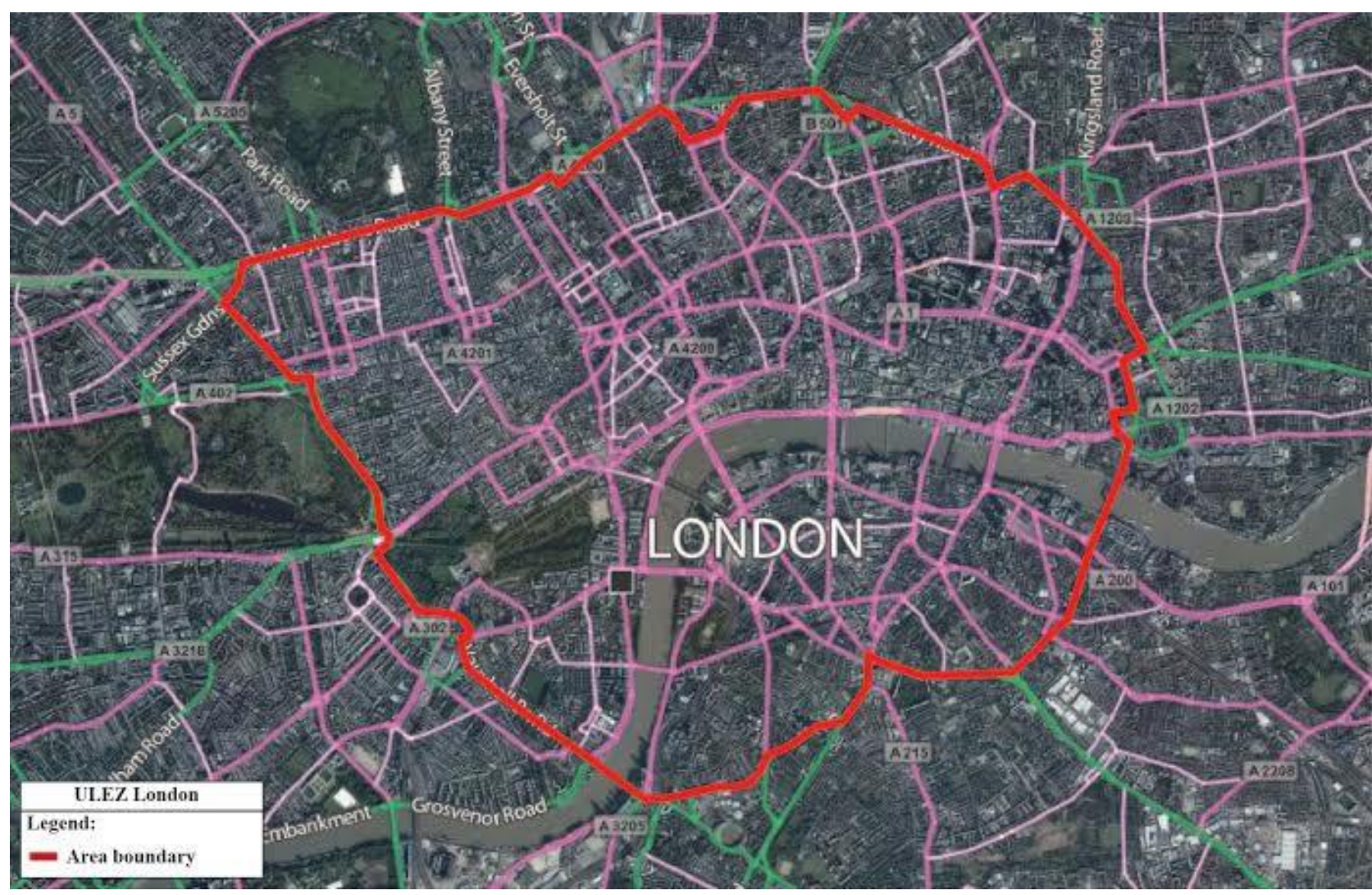

Fig. 2 - Ultra Low Emission Zone in London 
ULEZ aims at reducing air-polluting emissions from road transport -including $\mathrm{CO}_{2}$, and at supporting mayoral strategies to achieve compliance with EU limit values. The introduction of road charging is one of the measures to promote sustainable travel, by increasing the proportion of low emission vehicles in London (Transport for London, 2014a). ULEZ will cover the same geographical area and will be implemented within the same boundaries as CCZ, operating 365 days a year, 24 hours a day (Transport for London, 2014b). The applied toll will be $12.50 £ /$ day for cars, motorcycles, mopeds, vans and minibuses (Euro 3 to Euro 6), and 100£/day for heavy goods vehicles (HGVs) and buses (Euro 6). In comparison to current levels, there is a significant toll increase for buses and HGVs. If a vehicle does not meet the emission standards and the daily charge has not been paid by the specified time, a penalty charge notice is issued to the registered keeper of the vehicle. This fee is preliminary quantified at 1,000£ for HGVs and $130 £$ for light vehicles (cars, vans, motorcycles), but the amount can be halved if the amount is paid within 14 days from the notification. Based on the King's London College calculations, the ULEZ proposal would deliver a further $15 \%$ reduction in $\mathrm{CO}_{2}$ emissions from road transport (Transport for London, 2014b). At regional level, this measure is expected to achieve a broader reduction in emissions than $\mathrm{CCZ}$, which involves not only the central London, but includes the entire city $(-3 \%$ of $\mathrm{CO}_{2}$ emissions) and the outer London ( $-1 \%$ of $\mathrm{CO}_{2}$ emissions).

\section{3) Distance-based charge in the Netherlands}

In 2007, the Dutch Council of Ministers decided to change the approach on vehicle-related taxes, with the introduction of an ambitious national road-pricing program. The aim was to improve mobility and accessibility to benefit the economy, to develop a fairer system that focuses on use of the road system rather than on vehicle ownership and replace current license fees and vehicle taxes to enhance the environment and to improve road safety. Accordingly, road users are expected to pay per kilometres effectively driven (Eisses, 2009). The plan was to introduce a countrywide, distance-based road-user fee for trucks by 2012 and to expand the system incrementally to all vehicles (about 8 million) by 2018 (Arnold et al., 2010). The measure presented some unexpected difficulties of implementation. Indeed, after the collapse of the Dutch government in 2010, the measure was shelved. However, there has recently been a raise of interest (van Meerkerk et al., 2015).

Two alternative schemes were proposed and evaluated (Geurs et al., 2010): a flat rate on all roads or environmentally differentiated prices, based on $\mathrm{CO}_{2}$ emissions. Referring to this last case, efficient cars will be rewarded in relation to the average tariff, while inefficient cars will be penalized. In both cases, the Dutch roadpricing scheme included the entire country street network. Regarding the differentiated rate according to the fuel efficiency, an increase of less polluting vehicles is expected but with a contextually significant reduction of $\mathrm{km}$ driven and consequently, $\mathrm{CO}_{2}$ emitted (-12\% by 2030; Geurs et al., 2010$)$.

Regarding the flat rate, the behavior change concerns choices related to travelling, such as: time and route and decision whether to travel or not (Gille, 2009). By the introduction of this measure, the proposed tariff for cars is $€ 0.030$ per $\mathrm{km}$, while the rate is expected to reach $€ 0.067$ per $\mathrm{km}$ at full implementation (year 2018). The unitary tariffs for other vehicles are planned to be $0.017 € / \mathrm{km}$ for commercial vans, $0.028 € / \mathrm{km}$ for buses, and $0.024 € / \mathrm{km}$ for trucks. The difference between the program start and the full implementation rates depends by the fact that the vehicle ownership taxes will not be phase out instantly, but gradually during the implementation of the measure (Arnold et al., 2010). Income from the new pricing scheme is equal to the income from current taxes, hence distance charging is not intended to generate extra national income (Eisses, 2009). The effects of this measure are not univocally defined: Geurs et al. (2010) indicate a reduction of $\mathrm{CO}_{2}$ emissions from the Dutch car park by about $4 \%$ in 2030, while Arnold et al. (2010) forecast for the year 2020 a $10 \%$ reduction of $\mathrm{CO}_{2}$ emission by passenger cars. 


\section{4) Pay-as-you-drive insurance in California}

PAYD is a form of road charging that includes several technical obstacles (e.g., monitoring costs, state insurance regulations and patents) in the implementation phase. To overcome such obstacles, the California Department of Insurance undertook a rigorous rulemaking process aimed at assessing the introduction of a PAYD scheme in the State (Bordoff and Noel, 2008a; Nelson et al, 2013). To be effective, PAYD requires an accurate check of the mileage data (Bordoff and Noel, 2008b), which is possible thanks to the technological development made in recent years. Insurer PAYD mileage reporting may be accomplished via a newly installed in-car hardware device that connects via industry standard cable to in-vehicle computers for odometer readings and then transmits mileage readings via cellular telephony, and frequent self-reporting with infrequent audits verifying odometer readings. Moreover, most of the new cars record mileage in the engine computer and new technologies such as global positioning system (GPS) transponders provide a means of wireless transmission that could be used to transfer mileage data to insurance companies. Licensed professionals such as safety and emission inspectors verify mileage every year, or even more frequently: they have to transmit data to insurance companies and ensure that the odometer was not tampered with by the user (Bordoff and Noel, 2008b). A mandatory state-wide implementation of the measure is required. Insurers must be financially incentivized to create PAYD products, because voluntary programs were found to be not effective in reducing GHG emissions (Raney, 2010). According to the preliminary estimations, PAYD would result in an $8 \%$ driving reduction from light-duty vehicles (cars, vans, pickup trucks, and sport utility vehicles). This reduction would mean 24 billion fewer miles driven and 1.2 billion fewer gallons of gasoline consumed, based on 2006 data (Bordoff and Noel, 2008a). Based on a price of 6.8 cents per mile driven, PAYD would generate $\mathrm{CO}_{2}$ reductions equal to $7 \%-9 \%$ of the total. This measure, which is part of a broader and integrated national strategy, is necessary to meet California's emissions targets for 2020; among the others, it also includes the introduction of alternative fuels (hydrogen, electricity) in the national vehicular fleet.

\section{FINDINGS AND POLICY IMPLICATIONS}

Despite the importance of the issue, the scientific studies that assess the carbon effects of road congestion charging are still not numerous. However, to the best of our knowledge, tables 1-3 provide a comprehensive summary on road pricing for carbon purposes. Along with the best practices described in section 3 , they measure the potentialities of road charging in terms of carbon reduction, so that some conclusions can be drawn.

First, among the different forms assessed in this paper, congestion tax presents the highest number of studies, probably due to the easier implementation. Almost $76 \%$ of the studies are simulations of expected impacts, while measured results are limited to six cases. The access fee proposed by policy makers and modellers ranges between $1 €$ and $10 €$, carrying to results in terms of $\mathrm{CO}_{2}$ reduction that are mostly comprised between $2 \%$ and $10 \%$. It is worthy to be mentioned that the studies are mainly provided for big cities: only Santos et al. (2000) assessed $\mathrm{CO}_{2}$ impacts on several UK cities of medium size (100,000 - 200,000 inhabitants). In terms of carbon efficiency, the costs to implement such measure are relatively low, and in most cases (e.g., London, San Francisco, Auckland) a couple of years of operation already grant an economic return on the investment. Although the broader scale and the social acceptance make the adoption of the road pricing distance scheme complicated to describe in aggregated terms, expected results may be quite promising: $-13 \%$ on average, with a peak in the city of Cambridge (-36\%). Finally, PAYD is a measure that has been mostly assessed in American cities, with more modest results: the expected $\mathrm{CO}_{2}$ reduction is comprised between $8 \%$ and $12 \%$. According to 
Antonissen et al. (2013), such ranges of carbon savings could be considered as medium-high values. These results point to road pricing (in the three forms of congestion charge, distance-based and PAYD) as one of the most effective carbon measures in comparison to others, such as car sharing and bike sharing schemes, or traffic management applications (i.e. variable speed limits, ramp metering and managed lines).

Referring to the attitude of policy makers towards these measures, two related aspects seem particularly relevant: the social acceptance and the use of the revenues. As far as the first point is concerned, road pricing is an acknowledged effective tool to move towards more sustainable transport systems, but it presents several difficulties in the implementation phase, such as technical difficulties, the resistance by lobby groups and politicians, and privacy problems (Schade and Baum, 2007). Policy makers have to be able to intercept requests from the population and support their decision with adequate community-oriented motivation. Carbon reduction may constitute one of such motivations and its broad assessment range has constituted a problem in the evaluation of the impacts so far, so that the carbon potential of road pricing does not seem fully exploited yet.

The second aspect is related to the use of revenues and it can partially contribute to increase the social acceptance of the measure. Road charging cannot be conceived only as a political decision to grant an income to the Municipality or to the State. Indeed, it has to provide users with concrete benefits, which are adopted to deal with climate change issues (global scale), but also to improve the transport service and infrastructural network at local level. The development of ecological projects, the renewal of road infrastructure and the improvement of public transport services can be part of this integrated approach (OECD and ITF, 2010). In this sense, the investments deriving from the income taxation should be strategically conceived, involving different temporal horizons and scales. On the one hand, citizens should perceive concrete results in the short term. On the other hand, policy makers have to earmark money for those long-term projects, which aim at solving strategic issues. To ease the social acceptance, policy makers should think also to fiscal incentives: in Stockholm, for example, charges paid for commuting trips are deductible from income taxes.

At a broader scale, a correct balance of push and pull measures seems to be a possible solution to increase the acceptance by the users. In this sense, road pricing has to be part of an integrated transport package, to be clearly defined within the urban mobility plans, which includes carbon issues explicitly (Nocera et al., 2015b). Only by adopting this approach and highlighting all the costs incurred transparently, it is possible to ensure both the correct allocation of resources and the equity in the evaluation phase of road pricing for carbon responses.

\section{CONCLUSIONS}

This paper has illustrated the importance of adopting road pricing schemes to foster climate change issues. Through this approach, road-pricing systems should no longer be considered separately from the rest of the policies adopted, but these should rather be analysed and integrated to the transport system. Information technology has contributed to this process hugely, helping the coordination and control of the transport system and improving its overall efficiency but not only for carbon purposes. The efficient use of such schemes should also call for political decisions orienting the choice of a robust value for the economic estimation for the correct assignment of the deriving benefits and for setting a priority order to policy solutions. Outside of the policy premises, the development of efficient procedures for the quantification of the spared amount of carbon seems necessary; it is also important to define the technological requirements and equipment necessary for an efficient and integrated operation - the latter aspects do not hold only for carbon purposes.

These assumptions are not merely theoretical: the studies analysed in this paper, even though they are not numerous in absolute terms, confirm the potential carbon effects of road congestion charges, provided that 
policy makers assume a broader awareness of the issue. Within this context, some obstacles make the process difficultly implementable. Among the others, we can recall the difficulties of an integrated transport policy, the fragility of traffic control authorities and the implementation of effective inspection and control actions. Furthermore, the lack of integration between the government authorities responsible for traffic control and the various transport operators and users are other relevant aspects. Finally, policy makers must be aware of the wide variety of conflicting aspects found in the proposed control measures in terms of both users and operators, as well as the implementation and maintenance costs of the basic technological devices that are required for the development of integrated systems, in addition to hiring specialized staff.

This paper has focussed only on the policy implications of the carbon reduction granted by the road charging, not discussing the methodological issues about the quantification and evaluation of the emissions. Future researches should investigate the appropriateness of the methods adopted to obtain such results, also quantifying in economic terms the expected benefits deriving from the avoided emissions. In this sense, it is particularly delicate to obtain a reliable evaluation of the effectiveness (Nocera and Cavallaro, 2014b), since economic values provided by literature range up to six orders of magnitude (Nocera and Tonin, 2014).

However, despite these methodological aspects, it is important to ensure that road pricing schemes will operate within a broad strategy of carbon reduction. To this aim, joint efforts are required among teaching and research institutions and the government and private sectors, in order to overcome difficulties hampering operating integration, encouraging the fast, widespread dissemination and consolidation of this concept. This would offer the opportunity to organize transport networks appropriately, serving as an initial step for integrating various traffic systems and enhancing their potential for taking action, as well as inspecting and overseeing these activities. The public interest, which includes the carbon issues and the consequences caused by climate change, may hence become an important driver for achieving such aim and for determining a rigorous assessment of the road charging impacts.

\section{BIBLIOGRAPHY}

AIRUSE, (2015), 'Low Emissions Zones in Central and Northern Europe', Action B8: Draft report on Low Emissions Zones in Central and Northern Europe, AIRUSE LIFE 11 ENV/ES/584, online at: http://airuse.eu/wpcontent/uploads/2015/02/15_B8_DRAFT-Low-Emissions-Zones-in-Central-AND-Northern-Europe.pdf. [05.02.2016]

Alam, S., McNabola, A., (2014) 'A critical review and assessment of Eco-Driving policy \& technology: Benefits \& limitations', Transport Policy, 2014, vol. 35, issue C, pp. 42-49

AMAT, Agenzia Mobilità Ambiente e Territorio, (2015) 'Emissioni atmosferiche da traffico in Area C, periodo Gennaio Dicembre 2014', Comune di Milano, online at: http://mediagallery.comune.milano.it/cdm/objects/changeme:41719/datastreams/dataStrem17702424305323537/content [05.02.2016]

Antonissen, T., Dijkstra, A., Dreher, S., De Hann, R., Heiber, I., Van der Kroon, P., Ludeking, M.,, Van Muiswinkel, K., Pandazis, J., Pascotto, L., Rieder, M., Trommer, S., Vreeswijk, J., Wilmink, I., Johansson, H., (2013) 'Identifying the most promising ITS solutions for clean and efficient mobility', Working Group for Clean and Efficient Mobility (WG4CEM), Mobility Forum, online at: http://www.imobilitysupport.eu/library/imobility-forum/working-groups/active/ict-for-clean-and-efficientmobility/reports-4/2332-wg4cem-final-report-131308/file [05.02.2016]

Arnold, R., Smith, V., Doan, J., Barry, R., Blakesley, J., DeCorla-Souza, P., Muriello, M., Murthy, G., Rubstello, P., Thompson, N., (2010) 'Reducing Congestion and Funding Transportation Using Road Pricing In Europe and Singapore', U.S. Department of Transportation, online at: http://international.fhwa.dot.gov/pubs/pl10030/pl10030.pdf [05.02.2016]

Banister, D., (2003) 'Critical pragmatism and congestion charging in London', International Social Science Journal 176, pp. 249-264 
Beevers, S.D., Carslaw, D.C, (2004) 'The impact of congestion charging on vehicle emissions in London', Atmospheric Environment 39 (2005) pp. 1-5

Bordoff, J.E., Noel, P.J, (2008a) 'The Impact of Pay-As-You-Drive Auto Insurance in California', The Hamilton Project, The Brookings Institution, online at: http://www.brookings.edu/ /media/research/files/papers/2008/7/payd-californiabordoffnoel/07_payd_california_bordoffnoel.pdf [05.02.2016]

Bordoff, J., Noel, P.J, (2008b) 'Pay-As-You-Drive Auto Insurance: A Simple Way to Reduce Driving-Related Harms and Increase Equity', The Hamilton Project, Discussion paper 2008-2009, July 2008, online at: http://www.brookings.edu/ /media/research/files/papers/2008/7/paydbordoffnoel/07_payd bordoffnoel.pdf [05.02.2016]

C40cities, (2011) 'London's congestion charge cuts $\mathrm{CO}_{2}$ emissions by $16 \%$ ', online at: http://www.c40.org/case studies/londons-congestion-charge-cuts-co2-emissions-by-16 [05.02.2016]

Coria, J., Bonilla, J., Grundström, M., Pleijel, H., (2015), 'Air pollution dynamics and the need for temporally differentiated road pricing', Transportation Research Part A 75 (2015), pp.178-195

Danielis, R., Rotaris, L., Marcucci, E., Massiani, J., (2011) 'An economic, environmental and transport evaluation of the Ecopass scheme in Milan: three years later', online at: http://www2.units.it/danielis/wp/Ecopass\%20\%203\%20years\%20later,\%20finale.pdf [05.02.2016]

Dix, M., (2013) 'Ultra Low Emission Zone', online at: http://www.cleanair.london/wp-content/uploads/CAL-264-TfL-FINALULEZ-Stakeholder-event-MD-slides-STATIC-141113.pdf [05.02.2016]

Eisses, S., (2009), 'The distance-based charging project in The Netherlands', online at: https://www.researchgate.net/publication/228884987 The distancebased charging project in the Netherlands [05.02.2016]

European Commission (EC), Directorate-general for energy and transport (2009) 'EU Energy and Transport in Figures, Statistical Pocketbook', European Communities: Luxembourg, 2009.

Ezah, C., Finney, K., Nnjide, C., (2015) 'A Critical Review Of The Effectiveness Of Low Emission Zones (LEZ) As A Strategy For The Management Of Air Quality In Major European Cities', Journal of Multidisciplinary Engineering Science and Technology (JMEST) ISSN: 3159-0040 Vol. 2 Issue 7, pp. 1860-1868

Fensterer, V., Küchenhoff, H., Maier, V., Wichmann, H.E., Breitner, S., Peters, A., Gu, J., Cyrys, J., (2014) 'Evaluation of the Impact of Low Emission Zone and Heavy Traffic Ban in Munich (Germany) on the Reduction of PM10 in Ambient Air', Int. J. Environ. Res. Public Health 2014, 11, 5094-5112; doi:10.3390/ijerph110505094

Ferreira, F., Gomes, P., Carvalho, A.C., Tente, H., Monjardino, J., Brás, H., Pereira, P., (2012) 'Evaluation of the Implementation of a Low Emission Zone in Lisbon', Journal of Environmental Protection (2012), 3, pp. 1188-1205

Frey, K., (2010) 'The Low Emission Zone (Umweltzone) in Berlin', Federal Environment Agency, Germany, online at: http://www.unece.org/fileadmin/DAM/thepep/en/workplan/urban/documents/Skopje/presentations/session4/1.low.emissio n.zone.pdf [05.02.2016]

Geurs, K., Haaijer, R., Meurs, H., (2010) 'The Dutch national kilometre charge: impacts on the Dutch car market and environment', paper for ERSA special session on road pricing, 19-23 August, 2010, online at http://www.sre.wu.ac.at/ersa/ersaconfs/ersa10/ERSA2010finalpaper1438.pdf [05.02.2016]

Gibson, M., Carnovale, M., (2015) 'The effects of road pricing on driver behavior and air pollution', Journal of Urban Economics 89 (2015), pp. 62-73

Gille, J., (2009) 'Road pricing, the case of The Netherlands, Innovation in Road Transport, Opportunities for Improving Efficiency', Seminar 2 October 2009, Lisbon, Portugal, online at: http://www.internationaltransportforum.org/Proceedings/Lisbon2009/2-Gille.pdf [05.02.2016]

Goodman, P., Galatioto, F., Namdeo, A., Bell, M.C., (2014) 'Newcastle/Gateshead Low-Emission Zone Feasibility Study: Vehicle Emissions and Air Quality Modelling', online at: http://www.newcastle.gov.uk/sites/drupalncc.newcastle.gov.uk/files/wwwfileroot/environment-andwaste/pollution/lez feasibility report.pdf [05.02.2016]

Gulipalli, P.K, Kockelmann, K.M, (2007) 'Credit-based congestion pricing: A Dallas-Fort Worth application', Transport Policy 15 (2008), pp. 23-32

Harmsen, R., Kroon, P., Ybema, J.R., Jespersen, M.S., Jordal-Jorgensen, J., (2003) 'International $\mathrm{CO}_{2}$ policy benchmark for the road transport sector', online at: https://www.ecn.nl/publications/ECN-C--03-001 [05.02.2016] 
Jensen, S.S., Ketzel, M., Nøjgaard, J.K., Becker, T., (2011) 'What are the Impacts on Air Quality of Low Emission Zones in Denmark? ', Trafikdage på Aalborg Universitet, online at: http://www.trafikdage.dk/papers 2011/31 SteenSolvangJensen.pdf [05.02.2016]

Kompfer, P., Reinhardt, W., (2008) 'ICT for Clean \& Efficient Mobility Final Report', Safety Forum, Brussels, online at: http://www.transport-intelligent.net//MG/pdf//CTforCleanEfficientMobility-final.pdf [05.02.2016]

Martino, A., (2012) 'Milano: From Pollution Charge to Congestion Charge' Tech. rep., TRT Trasporti e Territorio, online at: http://www.trt.it/document/Martino\%20-\%20AreaC\%20Milano.pdf [05.02.2016]

Mitchell, G., Namdeo, A.K., Milne, D.S., (2005) 'The air quality impact of cordon and distance road user charging: an empirical study of Leeds', U.K Atmospheric Environment, 39 (33). pp. 6231-6242

Nelson, M., Pasterz, A., Stanlak, A., (2013) 'Pay-As-You-Drive insurance, Options for the University of Oregon', online at: http://ppms.trec.pdx.edu/media/project files/PAYD Team Project Final Paper 3-15-2013.pdf [05.02.2016]

Newbery, D.M. (1990) 'Pricing and congestion: Economic principles relevant to pricing roads', Oxford Review of Economic Policy, 6-2: pp. 22-38

Nocera, S., Cavallaro, F. (2014a) 'The Ancillary Role of $\mathrm{CO}_{2}$ Reduction in Urban Transport Plans', Transportation Research Procedia 3: 760-769. doi: 10.1016/j.trpro.2014.10.055

Nocera, S., Cavallaro, F., (2014b) 'A methodological framework for the economic evaluation of $\mathrm{CO}_{2}$ emissions from Transportation', J. Adv. Transp. 2014; 48:138-164. DOI: 10.1002/atr.1249

Nocera, S., Tonin, S., (2014) 'A Joint Probability Density Function for Reducing the Uncertainty of Marginal Social Cost of Carbon Evaluation in Transport Planning'. In: J. F. de Sousa and R. Rossi (eds.), Computer-based Modelling and Optimization in Transportation, Advances in Intelligent Systems and Computing 262: pp. 113-126. doi: 10.1007/978-3319-04630-3_9

Nocera, S., Tonin, S., Cavallaro, F., (2015a) 'The Economic Impact of Greenhouse Gas Abatement through a MetaAnalysis: Valuation, Consequences and Implications in terms of Transport Policy', Transport Policy, 37: pp. 31-43. Doi: 10.1016/j.tranpol.2014.10.004

Nocera, S., Tonin, S., Cavallaro, F., (2015b) 'Carbon Estimation and Urban Mobility Plans: Opportunities in a Context of Austerity', Research in Transportation Economics, Volume 51, September 2015, pp. 71-82. DOI: 10.1016/j.retrec.2015.07.009

OECD, ITF, (2010) 'Implementing congestion charges', International transport forum, online at: http://www.internationaltransportforum.org/itrc/discussionpapers/DP201012.pdf [05.02.2016]

Percoco, M., (2013) 'Is road pricing effective in abating pollution? Evidence from Milan', Transportation Research Part D 25 (2013) : pp. 112-118

Raney, S., (2010) 'Pay-As-You-Drive (PAYD) Auto Insurance to Reduce Driving by 8\%', online at: http://docplayer.net/5982421-Pay-as-you-drive-payd-auto-insurance-to-reduce-driving-by-8.html [05.02.2016]

Rotaris, L., Danielis, R., Marcucci, E., Massiani, J. (2010) 'The urban road pricing scheme to curb pollution in Milan, Italy: Description, impacts and preliminary cost-benefit analysis assessment', Transportation Research Part A: Policy and Practice 44-5: pp. 359-375

Santos, G., Rojey, L., Newbery, D., (2000) 'The environmental benefits from road pricing', Department of Applied Economics Cambridge, England, online at: http://citeseerx.ist.psu.edu /viewdoc/download?doi=10.1.1.203.753\&rep=rep1\&type=pdf [05.02.2016]

Schade, J., Baum, M., (2006) 'Reactance or acceptance? Reactions towards the introduction of road pricing', Transportation Research Part A 41 (2007), pp. 41-48

Shladover, S.E., Barth, M.J., Zhang, W.B, (2011) 'Engaging the International Community: Research on Intelligent Transportation Systems (ITS) Applications to Improve Environmental Performance', online at: http://ntl.bts.gov/lib/44000/44600/44663/FHWA-JPO-11

145 Research on ITS Apps to Improve Enviro Perform V2 Final.pdf [05.02.2016]

Sinha, K.C., Labi, S. (2007) 'Transportation Decision Making - Principles of Project Evaluation and Programming', New York, John Wiley and Sons 
Small, K.A., Yan, J. (2001) 'The value of "value pricing" of roads: Second-best pricing and product differentiation', Journal of Urban Economics 49-2: pp. 310-336

Strompen, F., (2016) 'Environmental zones, towards better air quality in inner cities, examples: Berlin and Milan', GIZ China | Transport Demand Management in Beijing, online at: http://www.tdmbeijing.org/files/Fact_Sheet_Environmental_Zones.pdf [05.02.2016]

Transport for London, (2014a) 'What do you need to know about Congestion Charging?', online at: http://content.tfl.gov.uk/ttl-cc-generic-leaflet.pdf [05.02.2016]

Transport for London, (2014b) 'Ultra Low Emission Zone consultation, supplementary information', online at: https://consultations.tfl.gov.uk/environment/ultra-low-emission-zone/user_uploads/ulez-supplementary-information--final-291014.pdf-1 [05.02.2016]

Van Meerkerk, J., Verrips, A., Hilbers, H., (2015) A Social Cost Benefit Analysis of Road Pricing in the Netherlands', CPB Background Document, online http://www.pbl.nl/sites/default/files/cms/publicaties/PBL_2015_A\%20Social\%20Cost $\% 20$ Benefit $\% 20$ Analysis $\% 20$ of $\% 20$ Road\%20Pricing\%20in\%20the\%20Netherlands_1876.pdf [05.02.2016]

Vonk Noordegraaf, D., Annema, J.A., van Wee, B. (2014) 'Policy implementation lessons from six road pricing cases', Transportation Research Part A: Policy and Practice 59: pp. 172-191

Washbrook, K., Haider, W., Jaccard, M. (2006) 'Estimating commuter mode choice: A discrete choice analysis of the impact of road pricing and parking charges', Transportation 33-6, pp. 621-639

Weinmann, V., (2014) 'Low Emission Zone (LEZ) Vehicle Travel Restriction to Improve Air Quality in Inner Cities'. Online at: http://www.transport2020.org/file/20140702-low-emission-zones-factsheet-en.pdf. [05.02.2016]

Wolff, H., (2014) 'Keep Your Clunker in the Suburb: Low Emission Zones and Adoption of Green Vehicles', Economic Journal. Doi: 10.1111/ecoj.12091

Yang, H, Bell, M.G.H. (1997) 'Traffic restraint, road pricing and network equilibrium', Transportation Research Part B Methodological 31-4: pp. 303-314 